\title{
Wprowadzanie w świat wartości w czasach chaosu aksjonormatywnego
}

\author{
Bring Value into the World in Times \\ of Axionormative Chaos
}

\begin{abstract}
ABSTRAKT
Ważne pytania dotyczq̨ce wychowania moralnego, pytania o wartości, którymi mamy kierować się w codziennych wyborach, dzisiaj nabieraja specjalnej ostrości i szukanie na nie odpowiedzi jest pilnie potrzebne. Upadek autorytetów, negatywne wzorce, relatywizm, ciagłe zmiany wszystko to utrudnia proces wychowawczy. Konieczność podejmowania działań wprowadzających dzieci i młodzież w świat wartości jest oczywista i bezdyskusyjna. Pojawia się jednak pytanie, jak to zrobić? Analizując badania prowadzone przez studentów w ramach prac dyplomowych, poświęcone wartościom oraz ich wdrażaniu w codzienne życie, pojawiały się liczne wątpliwości i refleksje. Poniższy tekst powstawał w wyniku licznych dyskusji prowadzonych ze studentami w trakcie opracowywania materiału badawczego i jest poszukiwaniem drogowskazów, które mogłyby pomóc w takim przekazywaniu wartości, by dziecko czy młody człowiek chciał uczynić je swoimi. Fundamentem wychowania moralnego jest dorosły, świadomy własnej hierarchii wartości, który ma wewnętrzne przekonanie o ich istocie i ważności. Kolejnym bezspornym elementem jest czas, który pozwoli budować relację autentycznq, pełnq zaufania, oparta na dialogu. Tylko w takiej autentycznej relacji, tworzqcej przestrzeń wolności, szacunku i otwartości na inność, jest szansa na poznanie, przyięcie i uznanie za swoje określonej hierarchii wartości.
\end{abstract}

SLOWA KLUCZOWE wartości, chaos aksjonormatywny, relacja, dialog, otwartość, wychowanie moralne

\section{KEYWORDS}

values, axionormative chaos, relation, dialogue, openness, moral education

SPI Vol. 21, 2018/4

ISSN 2450-5358

e-ISSN 2450-5366 DOI: 10.12775/SPI.2018.4.004

Nadestano: 31.10 .2018 Zaakceptowano: 10.12.2018

Artykuły i rozprawy 


\section{ABSTRACT}

It seems that questions regarding moral education, questions about the values that we are supposed to follow in our daily choices, have today taken on a special focus and the search for answers to them is urgently needed. The collapse of authorities, negative patterns, relativism, constant changes - all of this hinders the educational process. The need to take actions that introduce children and youth to the world of values is obvious and undisputed. However, the question of how to do so arises. Analyzing the research conducted by students as part of their diploma theses devoted to values and their implementation in everyday life has caused the appearance of numerous doubts and reflections. The following text was drafted over the course of many discussions conducted with students during the development of research material and is a pursuit of clues that might help in the transfer of values so that a child or young man could make them their own. It seems that the foundation of any moral education is the adult, aware of his own hierarchy of values, who holds an inner conviction about his essence and validity. Another indisputable element is the time that will allow the building of an authentic, trustful relationship based on dialogue. Only in such an authentic relationship that creates an area of freedom, respect and openness to otherness is there a chance of getting to know, accept and acknowledge a specific hierarchy of values as one's own.

\section{Wprowadzenie}

Wydaje się, że właśnie dzisiaj pytania dotyczące wychowania moralnego, pytania o wartości, którymi mamy kierować się w codziennych wyborach, nabierają specjalnej ostrości i szukanie na nie odpowiedzi jest pilnie potrzebne. Upadek autorytetów, negatywne wzorce, relatywizm- wszystko to utrudnia działania wychowawcze. Wielu autorów wskazuje, że obecny kryzys moralny oraz brak umiejętności odnalezienia się we współczesnym świecie, spowodowany jest licznymi i bardzo szybkimi przemianami społeczno-ekonomicznymi, technologicznymi czy politycznymi. Jako jednostka i jako społeczeństwo bardzo często nie potrafimy odnaleźć się w tych ciągłych zmianach i budować względnie trwałej, własnej hierarchii wartości. 
Odnosi się wrażenie, że współczesna rzeczywistość jest zawieszona niejako w aksjologicznej próżni, bazuje na kulturze typu instant nawiązującej do konieczności życia w natychmiastowości. Jest to powiązane $z$ rozwojem środków masowego przekazu i dostępności wielu form rozrywki, oraz triadą ,fast food, fast car, fast sex”, według których najistotniejsza w życiu jest konsumpcja, natychmiastowa satysfakcja, bez wszelkich przygotowań, starań, uczuć, bazująca wyłącznie na szybkim zaspokojeniu potrzeb ${ }^{1}$.

Irena Koźmińska i Elżbieta Olszewska ${ }^{2}$ w swojej książce $Z d z i e-$ ckiem w świat wartości wspominają o dorastaniu współczesnych dzieci w toksycznym świecie. Uważają, że jest to przyczyna wszelkich problemów emocjonalnych, uzależnień, zaburzeń zachowania czy depresji. Dziecięcy świat, pozbawiony często miłości rodzicielskiej, czasu, stymulacji intelektualnej, autorytetów, pozbawia również szans na tworzenie systemu wartości, ochrony przed błędnymi wyborami, złym towarzystwem itd. Współcześni rodzice, często pochłonięci pogonią za pracą, krytykowaniem, porównywaniem z innymi dziećmi, niszczą wzajemne relacje i więzi stojące u podstaw systemu wartości. Dzieci natomiast cierpią na „anemię emocjonalną”, wybierają najprostsze rozwiązania i szukając chwilowych kontaktów podnoszących ich samoocenę, kreują wyidealizowany wizerunek na portalach społecznościowych, mając tysiące wirtualnych znajomych a żadnego przyjaciela w rzeczywistości.

Konieczność podejmowania działań wprowadzających dzieci w świat wartości jest oczywista i bezdyskusyjna. Te oddziaływania ukierunkowane na wartości można zdefiniować jako „wspomaganie wychowanków w urzeczywistnianiu własnej i właściwej hierarchii wartości prowadzącej do pełni człowieczeństwa”3. Analizując różnorodne definicje wychowania, niejednokrotnie odnajdujemy w nich

1 Por. Z. Melosik, Edukacja, mtodzież i kultura wspótczesna. Kilka uwag o teorii i praktyce pedagogicznej, „Chowanna” 2003, t. 1(19), s. 19-37, <http:// bazhum.muzhp.pl/media//files/Chowanna/Chowanna-r2003-t1/Chowanna-r2003-t1-s19-37/Chowanna-r2003-t1-s19-37.pdf> [dostęp: 16.07.2018].

2 Por. I. Koźmińska, E. Olszewska, Z dzieckiem w świat wartości, Warszawa 2017, s. 17-19.

3 K. Chałas, Wychowanie ku wartościom - podmiotowe trudności realizacji w praktyce edukacyjnej, w: Wartości w pedagogice, red. W. Furmanek, Rzeszów 2005, s. 297. 
odwołanie się do wartości. Wychowanie bez wartości właściwie nie istnieje. Mocno ten element został zaznaczony przez Bogusława Śliwerskiego, który pisze, że wychowanie to całokształt procesów i oddziaływań zachodzących w toku wzajemnych relacji między co najmniej dwiema osobami, które pomagają sobie urzeczywistniać i rozwijać swoje człowieczeństwo. Tak rozumiane wychowanie zakłada uznanie i afirmację wolności, bo to dzięki niej strony interakcji mogą ujawniać i urzeczywistniać wobec siebie wartości, które nadają sens ich życiu. W tak rozumianym wychowaniu spotykające się ze sobą osoby, wzajemnie obdarowują się swoim człowieczeństwem. Wychowanie nie jest więc czymś, co pedagog „robi” dziecku, ale czymś, co oboje czynią razem ${ }^{4}$.

Ta droga do zbudowania własnej hierarchii wartości jest długa i trudna. Nie może być inaczej - tylko wówczas coś jest cenne, posiada wartość, gdy okupione jest wysiłkiem, trudem, wyrzeczeniem. Zbigniew Marek podkreśla, że wychowanie moralne to długotrwały proces, podczas którego człowiek odnajduje swoje miejsce w społeczeństwie, poznaje lepiej świat, może wpływać na dane społeczeństwo, zmieniać, przetwarzać i modyfikować je. Kluczowym elementem tego procesu jest przyjęcie i uznanie przez jego uczestników za swoją określonej hierarchii wartości, tak aby podczas jego przebiegu przyświecały im konkretne ideały etyczne, wzory postępowania ${ }^{5}$.

Przygląająąc się tym i wielu innym wypowiedziom, które podejmują kwestie wychowania, wychowania moralnego, a także analizując materiał badawczy gromadzony przez studentów podczas badań do prac dyplomowych ${ }^{6}$, zrodziło się pytanie i wątpliwość dotycząca warunków, czynników, elementów, które będą umożliwiały taki przebieg procesu wprowadzania młodego człowieka w świat wartości, by ten chciał je poznawać, by mógł się nimi zachwycić, by widział i zrozumiał ich znaczenie, by chciał uczynić je swoimi drogowskazami w życiu.

4 Por. B. Śliwerski, Program wychowawczy szkoty, Warszawa 2001, s. 33.

5 Por. Z. Marek, Podstawy wychowania moralnego, Kraków 2005, s. 41.

6 Prace licencjackie - niepublikowane: A. Giemzik, Wychowanie do wartości w nauczaniu wczesnoszkolnym w opinii nauczycieli klas 1-3; D. Wysmołek, Wychowanie do wartości w opinii rodziców miejskiego przedszkola samorzadowego w Suchej Beskidzkiej, promotor R. Królikiewicz. 
Pytanie o te czynniki wielokrotnie stawia sobie duża część rodziców i wychowawców. Rodzic, pedagog, wychowawca, nauczyciel ${ }^{7}$ świadomy odpowiedzialności za rozwój moralny swojego dziecka, staje przed pytaniem, jak uczyć, jak przekazywać wartości, by chciało ono uczynić je swoimi. Szczególnie, gdy cały czas trzeba „konkurować" z wzorcami i propozycjami przedstawianymi w wszechobecnych mediach.

\section{Przewodnik fundamentem wszelkich działań wprowadzających w świat wartości}

Czymś oczywistym jest, że nie ma jednej gotowej recepty na sukces w tej materii. Warto jednak, a nawet należy poszukiwać tych elementów, które mogą to prawdopodobieństwo zwiększyć. W rozwoju człowieczeństwa niezbędna jest pomoc wychowawcy - przewodnika. Jego obecność zdaje się być fundamentem wszelkich działań wprowadzających w świat wartości. Katarzyna Olbrycht słusznie zauważa, że zadaniem rodziców/wychowawców nauczycieli w wychowaniu moralnym jest stwarzanie sytuacji sprzyjających kształceniu intelektualnego rozpoznawania wartości, ich nazywania i uzasadniania ich miejsca w określonej hierarchii, kształcenie uczuć wyższych dynamizujących realizacje wartości ${ }^{8}$. Warunkiem niezbędnym do realizacji takiego zadania jest osobowa dojrzałość rodzica/wychowawcy/nauczyciela, jego stała praca nad tą dojrzałością, jasna hierarchia wartości i odwaga ujawniania powodów ewentualnych jej zmian. Zaniedbywana pedagogizacja rodziców i pozostawiająca wiele do życzenia formacja nauczycieli to w wielu przypadkach element, od którego należałoby rozpocząć. Świat dorosłych to często świat ludzi pogubionych, nieświadomych własnych celów i własnej hierarchii wartości. Potrzeba nam refleksji nad sensem i celem własnego życia. To zadanie, przed którym staje współczesny

7 Jednym $z$ tych elementów jest współpraca środowiska rodzinnego, szkolnego, pozaszkolnego i w miarę jednolity przekaz co do przekazywanych wartości o co bardzo trudno we współczesnej rzeczywistości. Temu zagadnieniu warto poświęcić osobne rozważania dlatego problem ten zaznaczony zostaje w powyższych rozważaniach poprzez zwrot: rodzic, pedagog, wychowawca, nauczyciel.

8 Por. K. Olbrycht, Dylematy wspótczesnego wychowania w świetle refleksji personalistycznej, w: Wychowanie na rozdrożu, red. F. Adamski, Kraków 1999, s. 17. 
dorosły, a jego wykonanie otwiera dopiero możliwość, by stawać się przewodnikiem dla młodszego pokolenia.

Może się przy tym okazać, że największym wyzwaniem i najtrudniejszą pracą, jaka stoi przed nami, dorosłymi, będzie praca nad sobą. Praca ta, podjęta dla dobra dziecka, będzie wyrazem naszej miłości do niego?

I jeżeli już na początku odnosimy wrażenie, że to zadanie niełatwe, warto podjąć ten trud i zacząć tam, gdzie to będzie możliwe z nadzieją, że nawet najdrobniejsze działania, powtórzone wielokrotnie, doprowadzą do faktycznych zmian i przestaną wydawać się walką z wiatrakami.

Janusz Mastalski ${ }^{10}$ pisze, że analiza tekstów filozoficznych Karola Wojtyły poświęconych człowiekowi ukazuje wartości-normy, które pozwalają na sformułowanie pewnych zasad wychowawczych. Są nimi wartość dobra i prawdy oraz wartość godności osoby. W świetle tych aksjomatów można przyjąć, że wychowanie wprowadza człowieka w świat wartości podstawowych: wolności, odpowiedzialności i miłości. Wolność jest darem, ale jednocześnie zadaniem, dlatego też trzeba ją stale zdobywać. Wychowanie do wolności jest równoczesnym wychowaniem do odpowiedzialności, a to prowadzi do wyjścia poza własny egoizm i skierowania się ku drugiemu. Poprzez miłość wychowujemy do miłości.

\section{Poznawać, odkrywać i zrozumieć wartości w atmosferze wolności, odpowiedzialności i miłości}

Mieczysław Gałaś podpowiada, że aby młody człowiek mógł zrozumieć znaczenie i sens wartości, należy stwarzać mu możliwości podejmowania samodzielnych wyborów z uwzględnieniem ich konsekwencji i świadomości odpowiedzialności za te wybory. Rolą dorosłego jest również pomoc w odkrywaniu i zauważaniu alternatyw w sytuacjach wyboru, antycypowanie i uwzględnianie konsekwencji każdego z możliwych rozwiązań, zastanawianie się nad tym, kim jestem, co cenię i szanuje, jakie wybory oceniam pozytywnie, o co się staram. Istotnym jest również umiejętne wyrażanie i akceptowanie

9 I. Koźmińska, E. Olszewska, Z dzieckiem w świat wartości, dz. cyt., s. 15.

10 Por. J. Mastalski, Zarys teorii wychowania, Kraków 2002, s. 128-131. 
własnych i cudzych wyborów oraz inspirowanie do postępowania zgodnego z podejmowanymi przez siebie decyzjami ${ }^{11}$.

Wynikają z tego bardzo praktyczne wskazania. Należałoby przede wszystkim uczyć oceny wartości, a nie dawać gotowych rozwiązań. Unikać nakazów, bo wszelki imperatyw działa krótko, a szansą jest pobudzanie do krytycznej oceny własnego postępowania. Istotnym elementem wydaje się również dbałość o precyzję i jasność określeń moralnych oraz nielekceważenie moralnych dylematów dzieci. Elementem, który w poznaniu i odkrywaniu wartości pełni istotne znaczenie, jest wiązanie teorii z praktyką, podkreślanie ich egzystencjalnego wymiaru. Stawiając wychowankom jasne, ale i dalekosiężne cele, należy zachęcać, motywować do ich osiągania ${ }^{12}$.

\section{Czas potrzebny na budowanie autentycznej relacji}

Wszystkie te wskazania potrzebują czasu na realizacje. Zakładają, że obie strony tego intensywnego i wielokrotnie obfitującego w trudności procesu dają sobie wzajemnie czas. Czas na wzajemne poznanie. Czas, który jest potrzebny na wyrażenie otwartości, okrycie wolności zrozumienie i przyjęcie odpowiedzialności. Wszystko, co może się wydarzać pomiędzy wychowawcą a wychowankiem, powinno się opierać na poszanowaniu godności drugiego i miłości. Czas pozwala tworzyć przestrzeń dla budowania relacji.

Relacja interpersonalna jest niezbędna w procesie wychowania. Charakterystyczne jest dla niej to, że jest dynamiczna, wciąż się zmienia i ewoluuje. Nie jest tworem gotowym, musi być każdego dnia na nowo budzona, pogłębiana i kształtowana. Więź, relację pełną miłości wyraża się w codzienności, to znaczy często w żmudnych czynnościach, powtarzanych gestach, słowach. Zadaniem rodziców jest przede wszystkim zaspokajanie potrzeb, zarówno tych fizjologicznych, psychicznych oraz społecznych. Dokonuje się to poprzez ciągłe $\mathrm{i}$ bezinteresowne podejmowanie wobec najmłodszego pokolenia

Zob. M. Gałaś, Wartość kultury w epoce wspótczesnej, Toruń 2000, s. 78;

K. Denek, Aksjologiczne aspekty edukacji szkolnej, Toruń 1999, s. 55.

12 Por. W. Czupryński, Wspótczesne koncepcje wychowania w rodzinie, Olsztyn 2010, <www.uwm.edu.p1/.../0-Współczesne-koncepcje-wychowania-skrypt. doc> [dostęp: 15.04.2016]. 
czynności opiekuńczo-wychowawczych nasyconych emocjonalnością oraz odpowiedzialnością ${ }^{13}$.

Jeżeli dziecko czuje się kochane i doceniane przez dorosłych, którzy je wychowują, będzie skłonne uznać ich za swych życiowych przewodników i przyjąć ich nauki. Natomiast próby wpajania wartości dzieciom przepełnionym goryczą i złością, gdyż nie otrzymują od najbliższych miłości, są skazane na porażkę. Można zmusić dziecko do posłuchu, ale nie można mu nakazać prawdziwego szacunku do ludzi, życzliwości ani miłości. Kiedy zniknie presja i nadzór ze strony autorytarnych rodziców lub nauczycieli, dziecko wyrazi swój bunt, odrzucając wszelkie wartości, które były dla nich ważne ${ }^{14}$.

Duża część społeczeństwa skarży się i wskazuje na brak czasu, pomimo wielu ułatwień, które daje nam rozwijająca się technologia i postęp. I tu stawiamy kolejne wyzwanie rodzicom/wychowawcom/ nauczycielom. Należy zawalczyć o czas dla wychowanka. Niejednokrotnie słyszymy deklaracje, że rodzina, dzieci, ich dobro jest najważniejsze. W praktyce niejednokrotnie brakuje czasu, by o tę deklarowaną wartość odpowiednio zadbać. Ważniejszymi stają się kolejne zlecenia, zawodowy awans, przyjemności. Nawet codzienne obowiązki częstokroć wygrywają z dzieckiem czekającym na uwagę, rozmowę, zabawę. Jeżeli autentycznie zależy nam - dorosłym, by ten świat wartości pokazać i wprowadzić w niego naszych podopiecznych, musimy znaleźć na to czas!

\section{Dialog - droga do zrozumienia}

Powyżej wspomniano, że jednym z utrudnień w procesie wychowania jest bardzo silne oddziaływanie mediów i popkultury, ogromna konkurencja w proponowanych postawach i kreowanych wzorcach. Od najmłodszych lat wychowankowie za sprawą niewłaściwych programów telewizyjnych, niestosownych gier i programów uczą się reagować złością, agresją, uciekając od wartości będących „drogowskazami postępowania”. Kultura konsumpcjonizmu i natychmiastowości

13 Por. J. Eukasik, Nauczyciel jako rodzic. Rola opiekuna wychowawcy we wspótczesnym świecie. Raport z badań, w: Rodzina w kontekście wspótczesnych problemów wychowania, red. B. Muchacka, Kraków 2008, s. 169.

14 Zob. I. Koźmińska, E. Olszewska, Z dzieckiem w świat wartości, dz. cyt., s. 40. 
staje się atrakcyjniejsza, bardziej pociągająca niż wartości, o których wspomina, czasami wymaga, ale niejednokrotnie nimi nie żyje rodzic/ wychowawca/nauczyciel.

Wielu młodych ludzi postrzega formalną edukację jako „zło” konieczne; nie jest ona dla nich źródłem sensu codziennego życia. To teksty kultury popularnej i jej bohaterowie stanowią źródło (re)konstruowania przez młodego człowieka własnego ,ja”. To nie nauczyciel od matematyki i pani od polskiego, lecz Michael Jordan i Cindy Crowford kształtują wzory osobowe; to nie treść „Lalki” Bolesława Prusa czy „Trenów” Jana Kochanowskiego jest omawiana na dużej przerwie, lecz artykuły drukowane w „Cosmopolitan” i „strategie przetrwania” $z$ najnowszej gry komputerowej. Młodzież coraz częściej żyje schizofrenicznie: przed południem odsiaduje swoje godziny w klasie szkolnej, po czym z zapałem oddaje się zajęciom, które uznaje za sensowne: lekturze „Elle”, dryfowaniu przez internetową „wirtualną rzeczywistość”, śledzeniu przebiegu rozgrywek amerykańskiej ligi NBA, słuchaniu muzyki Spice Girls czy Britney Spears ${ }^{15}$.

Niemożliwe jest odseparowanie młodego człowieka od tego wszystkiego, na co ja jako rodzic/wychowawca/nauczyciel nie daję zgody.

Tu z pomocą przychodzi dialog. Jak podaje Marian Śnieżyński,

[...] dialog to wzajemna wymiana myśli co najmniej dwóch osób, w którym dochodzi do wymienności ról nadawcy i odbiorcy z pełnym poszanowaniem prawa do podmiotowości ich uczestników, z poszanowaniem prawa do własnych poglądów, celem wzajemnego poznania się i zrozumienia prowadzącego do wzajemnego zbliżenia się osób ${ }^{16}$.

Umiejętność dialogowania to umiejętność wsłuchania się w rozmówcę, to autentyczne zaangażowanie w jego sposób myślenia, rozumowania, to chęć spotkania, z którego wynika dobro. Śnieżyński prowadząc rozważania dotyczące sztuki dialogu podkreśla, że „aby osiągnąć pełnię dialogu, najpierw należy nawiązać kontakt z uczniem poprzez komunikację, następnie ubogacić ją relacjami interpersonalnymi, w których szczególną rolę pełnią zasady miłości i podmiotowości” ${ }^{17}$, i dopiero na tym fundamencie można przejść do wspólnego odkrywania prawdy, kompromisu i konsensusu.

15 Por. Z. Melosik, Edukacja, mtodzież i kultura wspótczesna. Kilka uwag o teorii i praktyce pedagogicznej, dz. cyt., s. 29.

16 M. Śnieżyński, Dialog edukacyjny, Kraków 2001, s. 9.

17 M. Śnieżyński, Sztuka dialogu teoretyczne zatożenia a szkolna rzeczywistość, Kraków 2005, s. 19. 
Jedną z zasad wchodzenia w dialog z drugim człowiekiem jest autentyczność rozmówców. Jeżeli ja - rodzic/wychowawca/nauczyciel jestem w pełni przekonany, że świat wartości, do którego chcę zaprosić mojego wychowanka jest atrakcyjny, ważny, to swoją postawą, codziennymi wyborami będę to potwierdzać. Mówienie to za mało, mój wychowanek powinien zobaczyć w moich działaniach wartości, którymi chcę się z nim podzielić. Nawet jeżeli początkowo je odrzuca, wyśmiewa, to może wkrótce one go zaintrygują, zaciekawią, może pojawi się przestrzeń na zatrzymanie i postawienie pytania, czym one są i co przynoszą? Zakładając, że człowiek pragnie dobra, należy umożliwić mu spotkanie się z nim. Autentyczność pozwala zachwycić się i uwierzyć w wartości, które czasami wydają się już zupełnie nieprzystające do współczesności. Każda wartość musi zostać osadzona w nowej, ciaggle zmieniającej się rzeczywistości.

Każdy z nas żyje w swoim czasie i warunkach, rzeczywistości charakterystycznych dla tego okresu, dlatego należy pamiętać, że $\mathrm{w}$ wychowaniu nie można przekazywać z pokolenia na pokolenie gotowych recept na życie, określonych i jedynie słusznych postaw, wzorców zachowań. Jest to niemożliwe i zupełnie nieprzydatne. Wychowujemy tak naprawdę do życia w świecie i rzeczywistości, której nie znamy, a o której John Dewey pisał:

Warunki istnienia nieustanie się zmieniają [...]. Niepodobna więc dzisiaj wychować dziecka, mając na oku jakieś jedno określone stanowisko w życiu. Wychowanie, które świadomie czy bezwiednie opierałoby się na takiej postawie, dawałoby w rezultacie nie obywateli, lecz trutni ustroju społecznego. Zamiast się zajmować sobą i innymi, byliby istotami wiecznie zależnymi. I tu więc zadania moralne szkoły należy pojmować w sensie jak najszerszym; wychowanie powinno dać dziecku panowanie nad sobą, niezależność, zdolność przystosowania się do zmian środowiska, lecz zarazem i zdolność wprowadzania samemu w nim zmian pożądanych ${ }^{18}$.

Postawa dialogu zakłada również otwartość i poszanowanie dla inności poglądów, racji, spostrzeżeń. Nie możemy udawać, że współczesny świat jest jednolity i jednomyślny. 


\section{Na zakończenie - świadomość odrębności}

Wszystkie działania, które podejmujemy, by wprowadzać młodego człowieka w świat wartości, zmierzają do ostatniego etapu, którym jest internalizacja, czyli przyjęcie danych wartości i uznanie za własne. Należy pamiętać o tym, że każdy z naszych wychowanków jest odrębną istotą, wolną i zdolną do podejmowania własnych decyzji. Świadomość tej odrębności powinna nam towarzyszyć podczas całego procesu edukacyjnego, wychowawczego.

Jolanta Dobrzyńska ${ }^{19}$ pisze, że wychowanie w personalizmie jest zawsze propozycją, jest możliwością a nie koniecznością, jest zatem także ryzykiem, ponieważ intencja wychowawcy nie wystarcza i projekt nie zawsze ma sposobność zrealizowania się. Wolność wyboru stanowi naturalne wyposażenie osoby i w żadnym wypadku nie powinien być narzucony przez wychowawcę. Janusz Homplewicz podkreśla, że „to jednostka sama musi, i to w sposób wolny i dobrowolny, a nie narzucony i przymuszony, uznać określone wartości, przyjąć, przeżyć i oswoić, by stały się cząstką jej świata osobowości”20.

Czasami bardzo trudno przyjąć i uszanować, że

[...] dziecko ma prawo do swobody myśli, sumienia i wyznania. Artykuł 14 Konwencji o prawach dziecka głosi, że rodzice i opiekunowie mogą „ukierunkowywać” dziecko w korzystaniu z tego prawa „w sposób zgodny z rozwijającymi się zdolnościami dziecka", ale generalnie ma ono swobodę wyrażania wyznawanej religii lub przekonań. Ma więc prawo do wiary w św. Mikołaja, ale również prawo, by w niego nie wierzyć. Ma prawo być chrześcijaninem, ale też ateistą, agnostykiem albo wyznawcą judaizmu, islamu, buddyzmu, hinduizmu czy Latającego Potwora Spaghetti²1.

Zadaniem, które ma wykonać rodzic/wychowawca/nauczyciel, to „[...] pomagać w poszukiwaniu i odkrywaniu wartości”22. Czy jesteśmy gotowi, by każdego dnia na nowo podejmować się tego istotnego zadania?

19 J. Dobrzyńska, Kierunki wychowawcze, w: Jak wychowywać? Prezentacja programów wychowawczych i rozwiqzań wspierajacych szkotę we wdrażaniu reformy, Poznań 1999, s. 44.

20 J. Homplewicz, Etyka pedagogiczna, Warszawa 1996, s. 171.

21 A. Golus, Przyznajmy dzieciom prawa cztowieka, <https://www.tygodnikpowszechny.pl/przyznajmy-dzieciom-prawa-czlowieka-155151> [dostęp: 22.08.2018].

22 I. Koźmińska, E. Olszewska, $Z$ dzieckiem w świat wartości, dz. cyt., s. 40. 


\section{Bibliografia}

Chałas K., Wychowanie ku wartościom - podmiotowe trudności realizacji w praktyce edukacyjnej, w: Wartości w pedagogice, red. W. Furmanek, Wydawnictwo Uniwersytetu Rzeszowskiego, Rzeszów 2005, s. 297-309.

Czupryński W., Wspótczesne koncepcje wychowania w rodzinie, Olsztyn 2010, <www.uwm.edu.pl/.../0-Współczesne-koncepcje-wychowania-skrypt. doc> [dostęp: 15.04.2016].

Denek K., Aksjologiczne aspekty edukacji szkolnej, Wydawnictwo Adam Marszałek, Toruń 1999.

Dewey J., Szkota i dziecko, przeł. H. Błeszyńska, Wydawnictwo E. Wende, Warszawa 1933.

Dobrzyńska J., Kierunki wychowawcze, w: Jak wychowywać? Prezentacja programów wychowawczych $i$ rozwiqzan wspierajacych szkote we wdrażaniu reformy, red. E. Ozimek, Oficyna Współczesna, Poznań 1999, s. 31-45.

Gałaś M., Wartość kultury w epoce wspótczesnej, Wydawnictwo Edukacyjne Akapit, Toruń 2000.

Golus A., Przyznajmy dzieciom prawa cztowieka, <https://www.tygodnikpowszechny.pl/przyznajmy-dzieciom-prawa-czlowieka-155151> [dostęp: 22.08.2018].

Homplewicz J., Etyka pedagogiczna, Wydawnictwo Salezjańskie, Warszawa 1996.

Koźmińska I., Olszewska E., Z dzieckiem w śrwiat wartości, Wydawnictwo Świat Książki, Warszawa 2017.

Łukasik J., Nauczyciel jako rodzic. Rola opiekuna wychowawcy we wspótczesnym świecie. Raportz badań,w: Rodzina w kontekście wspótczesnych problemów wychowania, red. B. Muchacka, Wydawnictwo Naukowe Papieskiej Akademii Teologicznej, Kraków 2008, s. 167-176.

Marek Z., Podstawy wychowania moralnego, Wydawnictwo WAM, Kraków 2005.

Mastalski J., Zarys teorii wychowania, Wydawnictwo Naukowe PAT, Kraków 2002.

Melosik Z., Edukacja, mtodzież i kultura wspótczesna Kilka uwag o teorii i praktyce pedagogicznej, „Chowanna” 2003, t. 1(19), s. 19-37, <http:// bazhum.muzhp.pl/media//files/Chowanna/Chowanna-r2003-t1/ Chowanna-r2003-t1-s19-37/Chowanna-r2003-t1-s19-37.pdf> [dostęp: 16.07.2018].

Olbrycht K., Dylematy wspótczesnego wychowania w świetle refleksji personalistycznej, w: Wychowanie na rozdrożu. Personalistyczna filozofia wychowania, red. F. Adamski, Wydawnictwo Uniwersytetu Jagiellońskiego, Kraków 1999, s. 11-19.

Śliwerski B., Program wychowawczy szkoty, Wydawnictwa Szkolne i Pedagogiczne, Warszawa 2001. 
Śnieżyński M., Dialog edukacyjny, Wydawnictwo Naukowe Papieskiej Akademii Teologicznej, Kraków 2001.

Śnieżyński M., Sztuka dialogu teoretyczne zatożenia a szkolna rzeczywistośc, Wydawnictwo Naukowe Akademii Pedagogicznej, Kraków 2005.

\section{ADRES DO KORESPONDENCJI:}

Dr Renata Królikiewicz

Akademia Ignatianum w Krakowie

Wydział Pedagogiczny

Instytut Nauk o Wychowaniu

e-mail: renata.krolikiewicz@ignatianum.edu.pl 